\title{
EMPLOYEE RETENTION FACTORS FOR SOUTH AFRICAN HIGHER EDUCATION INSTITUTIONS: A CASE STUDY
}

\author{
FG NETSWERA \\ Council for Scientific and Industrial Research (CSIR) \\ EM RANKHUMISE \\ Department of Human Resources Management \\ Tshwane University of Technology \\ Rankhumiseem@tut.ac.za \\ TR MAVUNDLA \\ Department of Health Studies \\ UNISA
}

\begin{abstract}
The success of the most competitive companies throughout the world, including higher education institutions, lies in their highly skilled employees on which these institutions spend millions to retain. Literature reveals the cost of losing best employees to be enormous - beyond monetary quantification. Also worth noting is that the loss of one competent employee to a competitor institution strengthens the competitor's advantage. This case study analysed human resources turnover data, and interviewed academic managers and employees in order to examine the possible employee retention factors for a higher education institution in South Africa. The findings reveal different institutional interests between institutional managers and employees. The former are concerned more about profits, business sustenance and justification for spending, while the latter are driven by introverted interests such as development, monetary rewards and personal fulfilment.
\end{abstract}

\section{OPSOMMING}

Die sukses van die mededingendste maatskappye regoor die wêreld, insluitende tersiêre opleidingsinstansies, lê in hulle hoogs opgeleide werknemers, en hierdie instansies spandeer miljoene om hierdie werknemers te behou. Volgens die literatuur is die koste verbonde aan die verlies van die beste werknemers enorm - baie meer as wat in geld uitgedruk kan word. Wat ook merkwaardig is, is dat die verlies van een bevoegde werknemer aan 'n mededingende instansie die mededinger se voordeel versterk. In hierdie gevallestudie is menslikehulpbronomsetdata ontleed en onderhoude met akademiese bestuurders en werknemers gevoer ten einde moontlike werknemerbehoudfaktore vir 'n tersiêre opleidingsinstansie in Suid-Afrika te ondersoek. Die bevindinge openbaar uiteenlopende institusionele belange tussen institusionele bestuurders en werknemers. Eersgenoemde is meer gemoeid met die wins, besigheidsinstandhouding en regverdiging vir besteding terwyl laasgenoemde gedryf word deur interne belange soos ontwikkeling, geldelike belonings en persoonlike tevredenheid.

An examination of employee retention literature reveals that efforts to retain employees are more focused on employees with core competencies or in core business units. Unfavourable working conditions and low and unattractive remuneration have in most industries and in specific skill areas led to skills migration, even between countries. Job hopping and skills migration have consequently become a global phenomenon and impact negatively on South Africa's post-apartheid job market. It is now common knowledge that skills flight from mainly the Southern African Development Community (SADC) is mainly to Europe, the United States of America (USA) and Australia, and has generally resulted in huge skills shortages in specific skill markets (Stanley, Russel \& Jacobse, 1990). In South Africa the current skills shortage as reflected in the proportion of vacancies in June 2003 was computing professionals (16.8\%), engineers $(11.9 \%)$, accountants and related accounting occupations (26.7\%), personnel and careers professionals (15.8) and economists (7.9\%). The Technikons put more emphasis on programmes in business and management (47\%) and in science, engineering and technology (33\%) in attempt of meeting skills demanded in the economy (DOL, 2003).

While South Africa has experienced skills flight, there is also an observed high influx of international universities. Increased student registration in these foreign universities poses another challenge - if this trend continues, a possible drop in student numbers in South African public higher education institutions may be expected. Subotzky (2003, p.417), however, believes that private universities, rather than purely competing for students and funds, are playing a complementary role in the development of South African human resources skills requirements.

Requests for copies should be addressed to: EM Rankhumise,

Rankhumiseem@tutac.za
The subject of staff retention has been explored extensively in the corporate sector, but what remains largely undocumented are the efforts of higher education institutions in retaining their valuable staff members.

\section{EMPLOYEE RETENTION COST}

According to the American Management Association, the biggest cost on turnover is that of replacing an employee who leaves. This cost is calculated conservatively at 30\% of an employee's annual salary and for those employees whose skills are in high demand, the cost can rise to two-thirds of their annual salary (Dibble, 1999). However, other studies have found the replacement costs of lost talent to be between $70 \%$ and $200 \%$ of the lost employee's annual salary (Kaye \& Jordan-Evans, 1999, p.29). Increasing aggressive recruitment and global demands have made retaining the scarce skills more difficult. The main shortcoming is not only losing key members, but the lost productivity and replacement cost. Very few institutions can afford to employ, train and allow their most valued and talented employees to leave, when it is difficult to find better replacements. Salopek (2000) and the IRS Report (2000) state that retention leaders need to do the following in order to avoid brain drain (in no order of priority):

- Managing people and not retention;

- Having a culture of caring, balanced with a tradition of excellence;

- Never soliciting employee feedback and then ignoring it;

- Keeping an eye on the high performers and rewarding outstanding performance;

- Viewing people management as a strategic management issue;

- Being relentless in pursuit of continuous improvement. 
Salopek (2000, p.20) views the following critical elements to be important if any organisation has to effect a good employee retention exercise:

- Communicating how each employee contributes to the corporate vision and mission;

- Developing a climate of trust;

- Improving the skills level of the managers who supervise professional staff;

- Providing management training, including effective leadership skills by emphasising development;

- Clarifying the understanding of employees' needs and reinforcement of frequent communication;

- Not burning workers out;

- Clarifying roles and responsibilities to accelerate learning contribution;

- Investing in maintaining ongoing commitment by paying the best talent what they are worth

While losing employees is a very costly exercise, the replacement costs incurred include advertising and recruitment expenses, orientation and training of new employees, decreased productivity until the new employee is up to speed and loss of customers who were loyal to the departing employee. Finding, recruiting and training the best employees represent major investment challenges. Once a company has captured talented people, the return on investment requires closing the back door to prevent them from walking out. The key role of human resources development professionals should be to lead the war for talent on behalf of their organisations (Kaye \& Jordan-Evans, 1999, p.29).

\section{THE RETENTION FOUNDATION AND CORE COMPETENCIES}

A review by Dibble (1999) suggests that retention starts long before an employee is recruited, that is, when describing the position intended to be filled. Job descriptions, recruitment, selection and orientation are the imperatives of retention. Why does retention commence before the actual employment is effected? If the job descriptions do not define what institutions are looking for, then recruits will not meet the requirements and, as such, will not stay. Certain considerations, such as employee potential for training and development, should, however, be taken into consideration. Central to institutional requirements is their direction embedded in their vision and mission. Departments within the institutions, through human resources, translate these into recruitment, training and development policies (Smit, 1997, p.19). A human resources management strategy therefore emanates from and is based directly on the corporate strategy. Competent human resources management planning that integrates policies, practices and procedures to achieve the right numbers of people in the right jobs at the right time is required (Horwitz, 1991, p.116).

Core business units and the respective competencies obviously vary from one institution to the next, depending on, among other things, competitive strategies and differentiation. All higher education institutions require clear objectives in line with their mandate and core faculties that address their target markets, be it community development or skills development (Tach \& Murphy, 1995). All institutions should therefore address the core competencies and human characteristics that are required for successful careers, responsible citizenship and a good life (Chickering \& Stewart, 1995). The current dilemma, however, is that retaining employees in the post-apartheid South African higher education system is not only limited to addressing core business activities and required competencies, but includes responsiveness to the national imperatives for redress such as employment equity and skills development initiatives.

\section{CASE STUDY METHODOLOGY}

Against the given background and literature and owing to the then perceived high employee turnover rate of the institution surveyed, which was 157 administrative and 49 academics in two years, the institutional researchers considered it important to assess the institution's retention efforts. The research aims and objectives were executed in three phases as follows:

Phase 1: This phase was aimed at identifying exit and employment trends. Quantitative analysis of the secondary dataset of the period between 1998 and 2000 from the Human Resources Department gave an indication of the exit and employment trends.

Phase 2: In this phase, the institutional management, that is the vice-chancellor, deputy vice-chancellors and deans of departments, were individually interviewed to identify what the institution considered to be its core business units and competencies. The assumption, also informed by literature, is that these competencies are vital for the institution to retain its employees.

Phase 3: Two categories of employees were individually interviewed, that is, those who had submitted resignations to leave the institution and those that had stayed with the institution for more than five years. The purpose of these interviews was to explore and describe employee retention factors. All resigning employees (23) who had resigned during the duration of the research were interviewed; however, 10 long-service employees were randomly selected.

Due to the sensitivity of the information and in line with research ethics, all interviewees were promised anonymity. Recorded information was transcribed, coded and analysed using Tesch's descriptive methods in themes and sub-themes (Creswell, 1994). The presentation of research findings in this article makes use of direct verbatim comments to foster a clear understanding of interviewees' original thoughts.

\section{DISCUSSION}

The findings of this project are discussed in their respective separate phases below.

\section{Phase 1: Employee turnover data}

The important question to answer in this phase of the project was: In which departments and what types of skills are mainly lost? The analysis revealed the following trends:

- A major loss of white employees, $78,6 \%$ (162), 48\% (100) of whom were female $(\mathrm{N}=206)$

- More administrative staff in academic departments, $76 \%$ (157), than the academics themselves, $23,7 \%$ (49), had left the institution during the period 1998-2000.

It is evident that the institution lost most white employees and replaced them with blacks in an equity redress effort. However, employment figures show similar trends. There is also very little to no evidence at all that suggests that the types and level of skills that the institution had lost were distinct in nature.

Phase 2: The identification of core business units and competencies

Interviews with the management component of the institution revealed the core business units and competencies to be imbedded in the institution's value chain mission, illustrated by figure 1 . 


\begin{tabular}{|c|c|c|c|c|}
\hline Market intelligence & $\begin{array}{l}\text { Academic departments/ } \\
\text { programmes }\end{array}$ & Learner support & $\begin{array}{l}\text { Academic Support } \\
\text { Division }\end{array}$ & \\
\hline $\begin{array}{l}\text { Identification of community, } \\
\text { experience } \\
\text { economic and industrial needs }\end{array}$ & $\begin{array}{l}\text { - Academics } \\
\text { - Programme developers } \\
\text { - Course/subject development } \\
\text { - Academic departments }\end{array}$ & $\begin{array}{l}\text { - Decentralised learner support } \\
\text { - Tutor system } \\
\text { - Counselling }\end{array}$ & $\begin{array}{l}\text { - Language editors } \\
\text { - Courseware developers } \\
\text { - Online support } \\
\text { - Information technology }\end{array}$ & A quality learning \\
\hline
\end{tabular}

Figure 1: Core business units and required competency identification

The figure depicts what management assumed to be the core business of the institution, that is, "to offer a quality learning experience to its learners". While academic departments are central to the facilitation of quality learning experience, this cannot be achieved without full support from other departments. The quality learning experience is seen as a value chain to which each business unit directly contributes. Each employee should therefore have a sense of purpose of being part of the core of the institution, that is, adopt an attitude that "without my contribution a lot could go wrong". "... in fact the services that are used to provide a better learning experience would always be determined by what the academics need ...".

This value chain business system encourages dedicated participation by all departments. However, all institutional activities are seen as a chain of events in which one precedes the other, starting with the marketing intelligence learning programmes, support and administrative support.

\section{Marketing intelligence}

The value chain of a higher education institution may begin with the marketing intelligence function, which consists of the country, community, economic and industry needs identification. Marketing intelligence precedes the planning and development of relevant academic programmes. "... in general the first phase of the value chain will be what would be the amount of marketing intelligence you use to arrive at the needs so that the relationship with industry tells us what kinds of programmes we need to develop ..."; "... the market will decide or will have to determine whether we have relevancy ... curriculum because ... they will look at market ... you don't deal with the needs, you will have problem with relevancy ...". In line with the proposed higher education restructuring, institutions are expected to produce graduates with quality and required skills in meeting learning needs for the reconstruction and development of the country (National Plan for Higher Education (NPHE), 2001).

\section{Appropriate learning programmes}

Once the market needs are identified, often by institutional planning and research, the onus is on the academic faculties to develop appropriate learning programmes in line with the market needs. This requires properly trained and competent academic personnel in the form of lecturers and professors. "... the conventional core businesses of any higher education institution would centre around the work of academics ..."; "... it will mostly be academics who look at the subject curriculum, its contents and how it needs to be distributed across a three-year or four-year degree period ...". As confirmed by Van Niekerk (1996, p.33), curricula should be contextualised in order to address the problems, topics and issues that face a society.

\section{Learner and academic support}

When appropriate programmes are developed and offered to distance learners, a need arises, that of supporting the learner. This aspect has been emphasised by Yorke (1999, p. 99), who says that learners should be offered guidance and academic support to complete their course. Distance learners study in solitude, and often feel cut off from the rest of the academic world. Without this support, they are inclined to become depressed or frustrated (McGivney, 2003, p.145). Gous (1996, p.51) maintains that these phobic students are seen to require proactive support from their institutions. "... we need to know what learner support will be required ..."; "... there are two phases of learner support: the learner support element that should be developed into courseware ... that is infused ...your ongoing learner support in the form of tutor system ...". This support may range from course counselling to presenting information communication technology (ICT) infrastructure. "... if you're going do it by Web-based, your online specialist all of that, but ultimately can only produce the technical environment, the people must again produce the learning experience using that as a vehicle ...".

\section{Administrative support}

This is seen to be running parallel to all academic and learner support processes and should be efficient. Where the human resources, finance and student administrations are inefficient, all other sections may be negatively affected. "... all of these activities are underpinned by administrative support throughout ...".

What emerged from these interviews was firstly that all institutional departments are dependent on each other, i.e. the efficiency of one is dependent on the other. Secondly, it can be deduced that although all departments are theoretically perceived to be 'equal', the academic functions, which are mainly faculties, remain in the 'core', with all other functions as 'supportive'.

\section{Phase 3: The employee retention factors}

Experiences were categorised into possible retention factors. These are factors that would facilitate the stay or exit by staff members from a higher education institution. The decision to leave or stay, however, depends on the perceived direction of an individual's priorities.

\section{Discriminatory practices}

Coming from the era of apartheid, it is evident that South African institutions are to some extent still characterised by racial intolerance. These respondents revealed racial, sexist, nepotism and favouritism practices to still cloud their daily activities. The existence of these practices is to be expected and therefore legislation was enacted in an effort to counter them, namely the Employment Equity Act, No. 55 of 1998, Labour Relations Amendment Act, No. 127 of 1998, etc. In terms of section 6 of the Employment Equity Act, No. of 55 of 1998, employees must be treated well and no person may be unfairly discriminated against, directly or indirectly, through any employment policy, on grounds that include race, gender, pregnancy, sexual orientation, disability, HIV status, conscience, ethnicity, marital status, political opinion and social origin. Where favouritism exists, favoured employees might stay and those discriminated against leave as reflected by these statements: "... good people coming here particularly the good black people, they get frustrated by subliminal racism ..."; "... it is like they want you to be grateful that they let you enter the institution ...". 
Economic relevance and sense of purpose

Other important considerations include the social, political and economic relevance of the institution. South African higher education provision, according to these interviews, is uneven. Irrespective of salaries, some staff members would opt to work for particular institutions because of their perceived reputation and relevance of their graduates in the job market. Similar sentiments were also echoed in the Human Sciences Research Council (HSRC) research conducted among Grade 12 learners on their choices of higher education institutions (HSRC, 2003). It is important to note, however, that the reason for the perceived reputation and relevance of some graduates is more the historical structure of higher education than individual institutions themselves. It is important, according to the NPHE (2001, p.37), to restructure higher education to produce market relevant graduates while also curbing the high dropout, retention and poor graduate rates.

Lack of focus can be fostered through either the institution, department and individual, or all of these. "... My idea was that I am going to be doing academic research and focus on study material development ... now the focus is on administrative processes and we have no opportunity to do academic work ...". Employees who are creative, self-motivated and energetic require stimulating work opportunities, personal challenge, growth and a contributing stake in the organisational action. If these good workers find that their jobs no longer provide these necessities, they will decide they are no longer suitable and will leave for a job that will meet their new challenges (Kaye \& Jordan-Evans, 1999, p.32).

\section{Management and governance}

Management's role in governance of the institution is revealed to be a critical area of institutional performance. Most managers and supervisors think that they can keep good employees 'with money'. Research suggests that $89 \%$ of managers truly believe it is largely about money. These managers put the responsibility for keeping key people squarely in the hands of their finance departments (Kaye \& Jordan-Evans, 1999, p.9). "... this is where managerialism is at its disadvantage and I think we are often over-managed and demotivated ..."; “... people's focus when they come to work should be to work and not all other things like performance management, leave, salaries, etc ..."; "... they don't even know what their staff needs...if we want to exist for the next 20 years, we must look after our staff ...". While line managers often shift responsibilities to either HR or top management, Kay and Jordan-Evans (1999) note that if you are a manager at any level, a front-line supervisor or project leader, you actually have more power than anyone else and perceived indecisiveness may be of concern to your employees.

\section{The institutional track record and growth potential}

The institutional track record, which includes the quality and employability of graduates, strengthens the reputation that an institution builds over time. While some historically black universities (HBUs) and technikons (HBTs) might have built a good reputation during the apartheid days, their comparative lack of resources in the new categorisation as "South African institutions" rather than black and white institutions impacts negatively on their current image. With this in mind, employees could prefer to work in the historically white universities (HWUs) than the former HBUs. Possible effects could also be high skills flight from the HBUs and HBTs. "... when I came it was very interesting, maybe because the student numbers were also high; now I am not sure if numbers will stop dropping and if I will have a job in the next 5 years ...". The NPHE (2001, p.36) has claimed that the drop in student numbers in the HBUs and HBTs between 1993 and 1999 by $9 \%$ and 138\%, respectively, is linked to instability in governance and declining quality. It is these factors that respondents believed were important when making a decision on whether to stay with the institution.
Salaries and other benefits

Salaries and other benefits are perceived by management as the primary motive in employment seeking and mainly in jobhopping behaviour. On the contrary, institutions that have high salaries and attractive benefits are not necessarily assumed to be the highest employee retainers. It is assumed that retention goes with other conditions of service. "... I am relatively not satisfied with my current salary and can get a better package in other institutions if I look hard but we get free parking, we used to get subsidised meals, we and our children study free, so it goes beyond my salary ...".

\section{Work environment}

Flexible working hours, a challenging job, a sense of purpose and minimal grievances between staff and employees provide a favourable work environment. In line with remarks by Dibble (1999), respondents also believed that an institution should help employees maintain a balance between personal and work life. In some institutions, practices such as making childcare facilities available on the premises and flexitime can make the difference between keeping and losing an employee. "... flexible work practices will never happen in this place ..."; "... if I want to go to other libraries, I don't need to fill in a request form for such a small trip ...".

The psychological environment, which provides support for handling stress, and physical support infrastructures such as a psychologist or a nurse, etc. on site provide a sense of security to employees. Often statements about the environment, caring attitude towards workers, etc. appear in the official statements of the organisations, but are not often practised in most work environments (Dibble, 1999, p.157).

Institutional policies and human resources practices such as performance management systems are again linked to line management functions. If badly and subjectively managed, they can negatively affect employee morale. Employees are motivated to put more effort into their work when activities follow rewards, but basing remuneration increases on performance ratings that are often subjective can demotivate employees (Dibble, 1999).

\section{Staff development and promotion}

Opportunities for promotion, training and development are among the most important reasons why employees stay, especially young and enthusiastic ones. Institutions spend millions in hiring, training and developing their employees. Most employees, however, leave upon completion of their developmental objectives. A similar study conducted amongst 13 British universities found that over a quarter of academics were in the top of their academic scale, which meant no promotion or progression beyond annual "cost of living" (IRS Report, 2000). "... I went to a couple of courses but nothing ever gave back into what I was doing, no promotion or salary incremental ...". Employees who feel that they have outgrown their portfolios and that further training does not enhance their career moves within the organisation opt to leave. "... it appeared to me that my opportunities for self-development were very much limited and I do not intend to stay in the same position for the coming ten years ...".

\section{The external environment}

Other important, but non-internal retention factors include reasons such as the social, political and economic factors that shape the country as a whole. Where individuals have spouses working in foreign countries, they are also likely to leave the country. The perceived political stability of the country, crime rate and other opportunities are also important influential factors: "... I want to raise my kids overseas not here in South Africa ...".

Although a number of retention factors were identified, probing for order of importance revealed profitability, stability and 
justified spending to be important to institutional management, whereas employees are driven by personal gains, such as salaries, self-fulfilment, developmental opportunities and better conditions of work.

\section{LIMITATIONS OF THE STUDY}

Due to the preconceptions that academic programmes are the core business of higher education, exit interviews were conducted amongst staff in the academic departments and therefore the study findings do not apply to the retention factors applicable to administrative staff.

\section{CONCLUSIONS AND RECOMMENDATIONS}

The given concept of a value chain, whose product is a quality learning experience, presented in this context as the core business of the institution presents a scanty idea of where retention efforts need to be targeted.

Secondary data on employee turnover that is analysed here does not show any peculiar or distinct patterns on the types of skills or business units in which people with certain skills come and go.

Although most of the retention factors identified here are static, that is, may apply throughout the industry, others are 'seasonal' or temporal. For example, a sudden drop in student numbers and merger announcements may cause panic and a review of a person's state of comfort.

On the basis of this project a number of questions emerged for possible further research:

- A comparison of the current employee turnover figures for the two historically distinct institutional types in South Africa, that is, the HBUs and the HWUs.

- The NPHE's indication of decreasing student figures in the HBUs poses a further research question: What is the direction of the horizontal movements in higher education since 1994?

The research recommends a large-scale survey to ascertain if the identified employee retention factors hold for all or most of the staff members, including administrative staff in higher education institutions. The recommended survey should also, through such methods as Thurstone's Law of Comparative Judgement, rank all the identified retention factors in order to present an order of importance for various departments, skills levels and biographical groupings.

\section{REFERENCES}

Chickering, A. W. \& Stewart, D. (1995). Considering the public interest. Liberal-Education, 81 (2): 17-19.

Creswell, J W (1994). Research Design: Qualitative and Quantitative Approaches. Thousand Oaks: Sage.

Dibble, S. (1999). Keeping Your Valuable Employees: Retention Strategies for Your Organization's Most Important Resource. New York: John Wiley \& Sons.

Gous, V. (1996). Support to distance learners: exploring the phobic phenomenon. Progressio, 18(2): 49-55.

Horwitz, F. M. (1991). Managing Resourceful People: Human Resource Policy and Practice. Cape Town: Juta.

HSRC (2003). From school to higher education - what Grade 12 learners choose. HSRC Review, 1 (1): 10-11.

IRS (2000). Recruitment \& Retention in Employment in UK Higher Education: Two Independent Reports. London.

Kaye, B. \& Jordan-Evans, S (1999). Love 'em or Lose 'em: Getting Good People to Stay. San Francisco: Berrett-Koehler Publishers.

McGivney, V. (2003). Staying or Leaving the Course: Noncompletion and Retention of Mature Students in Further and Higher Education. Leicester: National Institute of Adult Continuing Education.

National Plan for Higher Education (2001). Ministry of Education: Pretoria.

Salopek, J. J. (2000). Career Centred: How do you keep great employees? Training \& Development, April: 24-26.

Smit, E. (ed.) (1997). Strategic Human Resource Management Pretoria: Kagiso.

Stanley, W. D., Russel, S S \& Jacobse, K (1990). International Migration and Development in Sub-Saharan Africa. Washington DC: World Bank.

South Africa. Employment Equity Act. No. 55 of 1998. Pretoria: Government Printer.

South Africa. Labour Relations Amendment Act. No. 127 of 1998 Pretoria: Government Printer.

South Africa. Department of Labour (DOL). 2003. State of skills in South Africa. Pretoria.

Subotzky, G. (2003). Private higher education and training. HRD Review. Pretoria: Human Sciences Research Council.

Tach, L. \& Murphy, K (1995). Competencies for distance education professionals. Education Technology Research and Development, 43 (1): 57-79.

Van Niekerk, J. L. (1996). Investigating the role of current theories of education in distance education. Progressio, 18 (2): 30-37.

Yorke, M. (1999). Leaving Early: Undergraduate Non-completion in Higher Education. London: Falmer Press. 